\title{
Baby boomers and their entourage
}

\author{
Catherine Bonvalet*, Céline Clément and Jim Ogg
}

\author{
Institut National d'Etudes Démographiques (INED), Université Paris X, France
}

\begin{abstract}
The post-war generation of baby boomers has witnessed major transformations in family life as well as being at the vanguard of them. A study undertaken in Paris and London in 2006 among 90 individuals born between 1945 and 1954 reveals, however, strong relationships with ageing parents and adult children. Family groups based on local or dispersed entourages, with regular contact and the exchange of support, are clearly identified. Other configurations include families where affective ties persist but contact between the baby boomers and their entourage is less frequent. Few baby boomers have replaced family members with friends or remain socially isolated. These results show that the rise of individualism associated with the baby boomers has not weakened intergenerational ties, although tensions exist between the demands of family solidarity and individual projects.
\end{abstract}

Keywords: family entourage; solidarity; network; inter-generational ties

\section{Introduction}

Since the nineteenth century, transformations to the family have raised many questions from both politicians and researchers. Characteristically, the family has repeatedly been described as being under threat from social change and modernity. It was feared in the nineteenth century that industrialisation and urbanisation would disrupt family ties (Le Play 1989), and in the 1950s that the nuclear family would supplant kinship ties (Parsons 1955). Towards the end of the twentieth century new concerns over the future of the family appeared with the first generations of baby boomers, defined here as persons born between 1945 and 1954. These concerns include the rise in single-parent families and reconstituted families, developments that are seen to jeopardise the future of filial relationships. As a result, since the beginning of the 1990s, there has been a rise in the number of studies on relationships and exchanges within families, particularly in the $\mathrm{UK}^{1}$ and France ${ }^{2}$.

Although inter-generational ties are better understood today, the role of the family is still often presented as being mainly instrumental, as for example its function to provide services and social capital. However, the fact that the post-war baby boomers assume - like their elders did before them - the role of a pivotal generation, by helping their parents with social care and integrating youth into the housing and job markets, does not tell us much about the various kinds of relationships among the different family members. As Roussel has remarked 'everything cannot be reduced to the parents' role as suppliers of assistance and 
the children as symbols of attachment' (Roussel 1996, p. 599). These roles are the visible manifestations of the complex exchanges between generations that are played out over the life-course and across several generations, according to the concept of indirect reciprocity in Maussian anthropology. Individuals pay off their debt to their own parents through their own children and do not anticipate any help from them in return. They do, however, expect their children to do likewise with their own children.

It is therefore important to understand the contemporary family over and above a purely instrumental vision of its role and to include its wider function in the context of the diversity of extended families. In the 1980s, the important work of Willmott (1986) suggested three main types of kinship configuration in contemporary urban England. The first was the 'local extended family', in which two or three separate households live near one another, meet on an almost daily basis, and regularly help each other out. Secondly, the 'dispersed extended family' also comprises two or three households, but not in the same location. Family contact is less regular than in the local extended family, but contact and assistance remains frequent. Thirdly, there is the 'dispersed kinship network', in which ties are weak, regardless of the location of the households.

This question of inter-generational bonds and extended modes of family organisation is all the more important because baby boomers have contributed to the emergence of new family bonds characterised by less conventional and more elective relationships. The diversity of the very forms of family that baby boomers have introduced, together with the massive entry of women into the labour market, has led some researchers to question their impact on kinship relationships (McGlone et al. 1999) and even to suggest abandoning the concept of the family in favour of 'primary relationships' (Scanzoni 1979). While the term is debatable (Cheal 1999, p. 63), it nonetheless has the merit of viewing the family through the prism of extended relationships within the kinship group. Indeed, the modern family has become, above all, relational (de Singly 2009), competing with other social networks. However, freely choosing one's family relationships can be in conflict with the moral obligations that bind family members to one another. Despite the rise in individualism - 'I' taking precedence over 'we' - family duties towards ageing parents and responsibility for children still weigh heavily in our societies. In addition the baby boomers are currently in an unprecedented generation situation. Between 50 and 60 years of age, they can be faced with the problems related to the old age of their parents and at the same time the difficult entry of their children into adult life. Certain questions still, therefore, need to be posed. Have baby boomers adopted more individualistic styles of behaviour while maintaining strong relationships with their non-cohabiting parents and children? If so, how do they reconcile their need for independence and freedom with new demands from within the family? Will they be altruistic or selfish, ask economists? (Masson 2009)

The aims of this paper are therefore twofold. First, to explore through a qualitative analysis of the narratives of members of the French and English cohorts of 1945-54 the question of whether, given the unique history of the baby boomers, the rise in individualism and personal autonomy which has accompanied the trajectory of the baby boomers is incompatible with the demands placed on them by ageing parents and children making the transition to adulthood. The second aim is to study the different types of extended family.

The conceptual framework that underpins the study draws upon two theoretical hypotheses. The first is that the notion of the baby boomer as a generational 
construct is relevant to understanding how agency interacts with structure and creates social change. In this respect, we pursue the contention put forward by Duane that 'society reflects, at any given time, the sum of its generations. Where one set of cohorts is especially large - like the Baby Boomers - its lifestyle dominates the society as it passes through the life course' (Alwin et al. 2006, p. 48). Baby boomers therefore share common experiences, particularly in cultural aspirations, even though there are many differences between them.

Second, to address these questions of inter-generational bonds and extended mode of family organisation, use can be made of anthropological concepts such as 'the group' and 'kinship networks' in order to analyse current family relationships. In anthropological terms, 'the group' refers to a quasi-fusion of households within an extended family; and kinship ties to 'a coalition of nuclear families in which closeness is experienced only from the perspective of a concern for reciprocal independence'. 3 The notion of 'private solidarity' therefore evokes the existence of a group, whereas mutual help refers to kinship. Although the anthropological concept of the group and kinship ties (Weber 2002) is difficult to discern on the basis of quantitative data, the indicators created by Vern Bengston, whose six-part classification of solidarity is widely used in Europe today (Bengston and Roberts 1991), do allow the functioning of such families to be better identified. According to the model, mutual help between individuals constitutes the 'functional' dimension of solidarity; the frequency of visits corresponds to the 'associative' dimension, and geographical distance to the 'structural' dimension. With the combined use of these different forms of solidarity, configurations of social ties emerge that go beyond descriptions of the immediate household (Gribaudi 1999). The task is to use this set of indicators to evaluate the strength of the relationships uniting households of the same kinship group and identify the system at work.

In France, this task began in the 1990s (Bonvalet and Maison 1999). Based on data from the study of 1946 persons representative of the French population, the Proches et Parents survey undertaken by INED in 1990 introduced the concept of 'family entourage' derived from Bengston's three criteria for inter-generational solidarity: affinities (to be among relatives considered 'close'); frequency of contacts (at least once a week); mutual help (a close relative has been helped by ego, or has helped ego). Within the family entourage, three categories can be distinguished: the local entourage, the dispersed entourage, and the isolated entourage. The first category corresponds to individuals living near a close relative with whom they have close ties. The second group includes individuals who maintain strong ties with a relative but do not live in the same locality. The third group represents individuals without an elective family network, i.e. people who do not have a family member in their social network. The findings from the Proches et Parents survey showed that the trend towards weak kinship ties was not the norm (see paper by Bonvalet and Lelièvre in this themed section).

We therefore decided to apply the concepts from the Proches et Parents survey to interviews conducted in relation with a research study on baby boomers in Paris and London (Bonvalet and Ogg 2009, Bonvalet et al. 2011) to determine the various forms of solidarity that link them to their parents and children and to identify whether the same patterns were present in the baby boomer cohort who, at the time of the study, were aged between 50 and 59. In 2006, in six different neighbourhoods (four in Paris and two in London), 90 respondents from the first baby boom 
generations (born between 1945 and 1954) were randomly selected to participate in a semi-directed interview covering their professional, family, and residential trajectories (30 in London and 60 in Paris). They were chosen, particularly in the case of Paris, primarily from the middle classes, that is to say they were neither part of the capital's elite nor lower social class groups.

Interviews were undertaken in the respondents' home by the authors and by two research students. A semi-structured questionnaire guided the interview, covering topics relating to residential trajectories, professional careers, and family life. Questions that are relevant for this paper included those on relations with parents and parents-in-law, with a focus on actual or potential care needs; the establishment of children in adult life and enduring responsibilities for young children from a second marriage or reunion; and the role of grandparenting and the implication of grandparents in looking after grandchildren. In situations where the respondents were grandparents and where at least one parent or parent-in-law was alive, respondents were asked about the organisation of support given respectively to these family members. A series of questions relating to the respondents' understanding of the terms 'generation' and 'baby boomers' was included. Each interviewer noted the key points and their impression of the respondent, their home, and the neighbourhood, immediately after the interview.

The interviews lasted on average one hour and 20 minutes and were digitally recorded. They were then transcribed verbatim, printed, and read by the three authors. Prior to the analysis, a summary sheet was compiled with the key sociodemographic characteristics of the respondent and the household. Two methodological approaches guided the analysis. Following Reinert $(1993,1995)$ a preliminary study of word frequency and the formal structure of their co-occurrences was undertaken using the software ALCESTE. An initial statistical classification of the narratives was made to determine patterns of the 'lexical world' of the narratives and their specific themes. The emergence of these themes guided the main analysis of the narratives, which took place in the context of a grounded theory approach (Glaser and Strauss 1967, Glaser 1998). The interviews were initially open-coded by each of the three authors according to themes that emerged from the classification analysis referred to above as well as the authors' own reading of the narratives. This coding structure was then compared, and a more refined coding category was developed by collapsing the themes into smaller units. The procedure was repeated, with interviews being re-analysed and coding categories compared and restructured until a stable corpus of themes evolved.

\section{Results}

\section{Local family entourage}

Among the 90 respondents, 36 belonged to a local family entourage (13 in London and 23 in Paris), a finding that reflects the earlier Proches et Parents survey and moreover one that reveals similarities between the two countries. One might have expected different behaviours in relation to the family to emerge from French and English baby boomers, in so far as the English are sometimes presented as being less attached to family values than their French counterparts. The 2006 baby boomer survey, however, as noted previously by Peter Willmott (1986), shows that the family 
remains central in both countries. Moreover, this finding is also confirmed by parallel data on residential proximity and contact that has been published from quantitative studies, such as the British Household Panel Survey (BHPS) in Great Britain, and $\mathrm{ERFI}^{4}$ and Biographies et Entourage in France. This relatively high proportion of baby boomers who belong to a local family entourage (40\%) can be in part explained by their specific position in the family life cycle: the pivotal generation, as described by Claudine Attias-Donfut (1995).

\section{The local family entourage: continuity and innovation}

In the life-course, there is a stage where demands for family support can coincide with the time when children leave the family home and when parents advance in age and require help and support. Sometimes referred to as a pivot or sandwich generation, in such a position 'a mutual support group is marshalled around a common cause' (Déchaux 2007, p. 99). Within this particular stage of the life-course, women, as might be supposed, play an essential role. They are often involved in finding accommodation close by for their newly independent sons or daughters and ensuring 'close care' for their elderly parents. When contact is daily and meals are often shared, the family functioning resembles a type of semi-cohabitation, as shown in the case of Martine, who provides a salient example of a local family entourage. Born in 1948 of Spanish parents, she had always lived in the same neighbourhood where her father was a craftsman. After her wedding, her uncle helped her to move into the flat above her father's workshop. Thereafter, Martine had had several homes. At the time of interview, she lived in the same building in which her father worked and her uncle resided. Quite naturally, she reproduced this life-style by setting up two of her children in an independent flat within the same apartment block linked by interphone. Since the family flat had become too small for their three children, several years previously Martine and her husband had decided to buy a two-room flat a floor down to be used as a playroom by the children. At the time of the interview, the youngest son was living in this flat, a second child had bought another flat with his fiancée in the same building, and the third had set up his home in the neighbourhood. Martine's parents, now deceased, used to live nearby, and two of her brothers still resided in the neighbourhood. The overall pattern of family functioning was one of frequent visits and omnipresent mutual support, whether in daily activities or at specific times, such as the purchase of a home. Martine reproduced a specific type of family, characterised by the values of work and family solidarity that she received from her craftsman father. In turn, she transmitted this mode of living to her children. In her particular case, the local family entourage partially encompassed the concept of the household ${ }^{5}$ in so far as there was an almost daily sharing of domestic activities on account of the emotional and physical closeness (in the building and the neighbourhood). In Martine's family, the household and kinship ties interlocked, and they were expressed through a deep-rootedness in a particular district of Paris. Family ties were based on solidarity, and they were anchored in the neighbourhood where she had lived as a child, as a parent, and where she hoped to become a grandparent. This solidarity extended well beyond the limits of the family, since her neighbourhood was a place in which she had invested for the last 15 years by volunteering in a charitable association. 
Local entourage families are often associated with strong geographical roots (Déchaux 2007), as can be also seen in the family history of Bill from England. Born into a working-class family in East London in 1950, Bill grew up in a threegenerational home with his grandfather and one of his uncles. After the birth of his brother, the family moved to a larger home in south London, away from the rest of the relatives. At the age of 11, his father died and his mother, who had just given birth to another son, had to move again. Single with three children, she decided to move closer to her extended family which was still living in East London. When he married, Bill left home to move into a rented flat in a nearby neighbourhood. He stayed there only a few years, however, and moved next to the county of Kent into company accommodation, where his two children were born. Six years later, he divorced and returned to London to live with his mother, who was at the time accommodating her daughter and son-in-law. At the beginning of the 1980s, Bill met his new partner and succeeded in obtaining social housing. A few years later, a rightto-buy scheme enabled him to purchase the home. At the time of the interview, Bill did not wish to move, although he had thought about returning to Kent. He and his partner had chosen for the time being to stay in their flat located near their family in order to give priority to contact with the family - his sister, who lived with his mother, as well as his children who had settled in neighbouring districts. These two examples, one from France and the other from England, both share a genealogical depth in so far as they involve several kinship groups. They also demonstrate the importance, as emphasised by Daniel Bertaux (1987) of understanding the nature of contemporary families by following them through several generations.

Depending on the history of the baby boomers and their parents, or even their grandparents, several types of local family entourages can be distinguished. Firstly, those that reproduce, as in the cases of Martine and Bill, a style of living 'as a family' that is shaped by family histories. Secondly, other baby boomers, themselves not necessarily from a local family entourage, had created this type of family by having established the family organisation and 'setting the children up' nearby (Bonvalet 2003). This strategy was adopted by Odile and her husband, who arrived as a young couple in Paris, leaving behind family and in-laws in the regions. A generation later, they arranged everything so that the family could function as a semi-cohabiting local family entourage. They purchased a flat in the neighbourhood for their eldest son and set up the second in a studio in the same building. This arrangement allowed frequent visits and family get-togethers. By purchasing property close by, the parents created the functioning of a local family entourage with their children. The local family entourage can therefore be present in different forms. Martine's local family entourage resembles a household or extended family living in several homes. It can be seen as an extension of the nuclear family, whereby parents, despite their residential separation, continue to be materially and financially present. This strategy can be temporary, with the children gradually moving away, or a more enduring arrangement of living together that respects the autonomy of each household. Some respondents have lived their whole lives near their parents, as we have seen in the case of Martine.

\section{The local family entourage: parents, siblings, and children together}

This type of family entourage, although not common, can be seen in the case Edouard, who described his family as 'old Parisians' because his entire family 
network (i.e. his parents when they were alive; his brother, who died a year prior to the interview; his sister-in-law, who lived practically next-door; and his sister) was located in Paris. The geographical proximity that is present in this type of family entourage is also accompanied by emotional closeness, which was manifest in occasional gatherings in the family holiday home in Brittany. Other baby boomers, sometimes as a result of their family history or a separation from their partner, form a local family entourage with their brothers, sisters, nephews, and/or nieces. This was the case of Paul. Paul was one of those baby boomers who embraced the counterculture of the 1960s, leaving his parents at the age of 17 to join a commune. Unlike some other baby boomers who had adopted counter-culture styles of living temporarily in their youth, Paul continued to live 'on the fringe' of society. After spending several years in Latin America, where he had a marriage of convenience to obtain a residence permit, he returned to Paris in 1985. Although Paul had grown apart from most of his family, he remained very close to one of his brothers. Indeed, this brother helped him upon his return, not only to find a job in a cultural association, but also to obtain a flat in Paris.

For the majority of baby boomers, family ties were certainly maintained, but they tended to be stronger with children than with parents. However, some baby boomers had, over the years, become more involved with their parents, either by moving nearer to them or by having their parents come to live near them. The relationships underlying these living arrangements, however, differed. With children, relationships were more spontaneous, whereas with parents they were maintained more from a moral obligation - a debt paid back to parents. This obligation could be clearly seen in cases where the parents needed help and support and where the previously 'smooth-running' local family entourage was imbibed with a heavy work-load for baby boomers. This was the case of Juliette who, although she had two brothers, took care of her aged parents alone:

My father is practically bedridden; he doesn't move any more... So, when my mother is ill, I have to go over there. So I drop in very, very regularly. It's hard ... because I have to run around all the time...

Several baby boomers had postponed plans to move away from the area in order stay near their parents. This was the case for James, in London. During the months prior to the interviews, he had become even more involved with supporting parents because his partner was also providing social care to her own parents. The couple were obliged to continue functioning as a local family entourage because of the onset of disabilities in their ageing parents. While relationships between the baby boomers and their parents appeared to remain very strong, they also showed signs of fatigue, resentment, and even, at times, rancour. There thus exists a double discourse, as has been observed by Vincent Caradec (2009). In situations where baby boomers provide prolonged social care to their parents or parents-in-law, relationships can become strained (Bonvalet and Maison 1999). While the baby boomers very often assumed their role of carer - or more precisely the daughters did - some showed signs of strain because their ability to improve the situation of their parents was limited. They find themselves all the more unprepared to assume their role as carers for their parents because support structures are inadequate in both France and England. The moral content of the baby boomers' narratives regarding their relationships with 
their parents who were not fully independent and the strain on relationships that this entailed was also observed in situations when adult children of the baby boomers returned to the family home because of difficulties in finding their own accommodation and stable careers. Under such conditions, the 'local family entourage' type of family is no longer experienced as positive and beneficial, but rather a situation that is enforced. In these types of situation, baby boomers had to adapt to new types of family relationships, although this process of adaptation was more likely to be made in the case of supporting children than parents.

\section{The local family entourage, or the art of being grandparents}

Baby boomers who formed part of a local entourage type of family maintained kinship relations predominately within a single lineage, i.e. ascendants and descendants. At the same time, it was relationships with children and, through them, grandchildren that tended to be privileged. For when grandchildren arrive, the local family entourage can be the ideal framework in which to exercise one's 'grandparentality', a status that was often expressed intensely by the baby boomers. Geographical proximity enabled them to establish regular patterns of help based on looking after grandchildren, although it should be noted that cases of threegenerational households or long periods of temporarily looking after grandchildren were rare. More often, the baby boomers stepped in to give their children some respite, either by looking after sick grandchildren or to give the parents a chance to take a holiday alone. However, with a few exceptions, most baby boomers did not devote equal time and energy to parents and children alike. Children and grandchildren took priority, followed by parents - or more specifically one's own parents, especially in the case of women. ${ }^{6}$ A local family entourage, however, did not jeopardise relationships with parents-in-law since they were integrated into the social network, but not necessarily at a local level. In these cases, baby boomer relationships with their family functioned on two levels - a local family entourage for the immediate family and a dispersed family entourage concerning the parents-in-law.

\section{Dispersed entourages families}

Home moves, professional mobility, and conjugal trajectories can result in the geographical separation of families. However, physical distance alone does not necessarily entail a weakening of family ties. Baby boomers who did not live close to other family members maintained close relationships, with weekly contact and regular exchanges of help and support. This family type can be seen to be one of a 'dispersed family entourage'. Of the 90 respondents in Paris and London, 32 belonged to this category (nine in London and 23 in Paris). The meaning of geographical dispersion should, however, be made clear. As we have seen, the local family entourage involves close proximity of family members and an anchoring in the same locality or a neighbouring one. This facilitates the sharing of domestic tasks (e.g. meals, housework, small repairs), and in some respects the 'local family entourage' is an extension of an extended family household. Because geographical distance separates 'dispersed entourages' family relations are organised in a different way. Distance does not appear to affect the quality of relationships or the intensity of inter-generational support, and the main characteristic that distinguished the 
dispersed family entourage from the local family entourage is the frequency of physical contact. It should also be noted that, over the life-course, families can move from a local to a dispersed family entourage and vice versa. For the baby boomers, families can move from a local to a dispersed entourage, as adult children leave the parental home and become independent. In cases where no adult children are left living nearby, the baby boomer parents may plan to move nearer to the homes of their children.

\section{The dispersed family: a well-tolerated life-style}

The 'dispersed family entourage' is a way of functioning as a family that requires a certain ability to manage long-distance relationships. This pattern can be observed in particular among higher social class groups and where career patterns are characterised by mobility (Bonvalet 2003). Among ethnic minorities or families that have a history of immigration, managing long-distance family relationships is also an integral part of family life, and one that is repeated from generation to generation. Holidays are important moments that bring dispersed families together. In the French context, a single 'family' home transmitted through the generations can be shared by dispersed family entourages and be the focus for reunions. As such, the 'second home' plays an essential role in the functioning of these families as a space that connects different generations (Gotman 1999).

As with the local family entourage, the examples of a 'dispersed family entourage' among the baby boomers showed how households and kinship ties were tightly interlocked. The case of Chantal, whose partner is a senior civil servant, perfectly illustrated this family type, typical of executives whose career paths have entailed many moves in France and abroad. For some baby boomers, mobility represented a 'habitus', and in these families members showed a greater aptitude for managing distant relations on account of knowledge and experience acquired over several generations. Chantal continued to support her youngest son, for example providing him and his young family with temporary accommodation prior to finding and buying their own home. The family remained dispersed but Chantal was not planning to leave their large house in the Parisian suburbs. She envisaged keeping the home as a central point around which the family can focus, especially her grandchildren who may come to Paris to study and for whom the grandparent's home would be particularly welcome as a temporary place to stay. In addition, a 'second' family home existed in the west of France, where larger family reunions were held every year.

In London, 61-year-old Mark provided a good example of a 'dispersed family entourage' that is characteristic of immigrants spread over several countries. Of Russian background, Mark had an international career. His only daughter, from his first marriage, had a child and was a journalist in Poland. Retired, Mark divided his time between his main residence in London and his two second homes, a house in Western England (that belonged to his current partner) and a house in Tuscany. Despite the distance separating Mark from his daughter, they met regularly, whether in England, Poland, or Italy, for holidays or family gatherings. Mark's case reveals one of the specific traits of baby boomers' family life, namely the complexity of family ties as a result of divorce. Mark evoked the need for 'arbitration' between his daughter and his current partner, who had two sons of her own, regarding the timing 
and content of family reunions. At Christmas in particular, different family ties and localities competed. In some cases, a second residence can be a place that divides families according to conjugal ties, whilst in other cases it can be a place that draws people together, helping to maintain, strengthen, and sometimes even build kinship bonds. Jacques' narrative is a typical example of a reconstituted family that creates new ties and in new spaces. Born in 1945, this former executive had four children: two daughters from a first marriage aged 38 and 36, and a 23-year-old daughter and an 18-year-old son from a second union. His two older daughters had children, including one who was almost the same age as his youngest son. Holidays were an occasion to reunite the whole family and beyond, as he described:

During holiday periods, we often rent several apartments ... There are my children, my ex-wife's children, her ex-husband's children, because she got divorced again afterwards ... there were 20 of us ... Well, stepfamilies just keep getting bigger...

The notion of place is fundamental in the functioning of such families through its structuring role in the kinship network. Place may be a second residence or a vacation spot somewhere equidistant for all family members. It can also be the home of the parents and/or parents-in-law. Moreover it is the genealogical depth to the homes and the historical significance that provides a territorial anchoring and legitimises feelings of belonging. These homes constitute a 'bricks-and-mortar anchorage', often reflecting the whole family's real attachment to its patrimony (Ramos 2006). There is also a perceived duty to keep such homes within the family. A house can therefore become a symbol of family coherence that must not be relinquished if it is to continue its role in the collective imagination as a lasting and immutable place that creates family ties and perpetuates the family lineage (Bourdieu 2000).

\section{$A$ dispersed family entourage as a result of constraints}

Whereas some baby boomers, mainly from middle and upper social class groups, were successful in managing their dispersed family entourage, our interviews revealed that baby boomers from lower-income families had more difficulties. ${ }^{7}$ The dispersed family entourage did not really meet the expectations of such households, and the local family entourage represented the 'ideal' mode of functioning. Martin, for example, regretted the loss of his local family entourage, describing the departure from the local neighbourhood of his parents, who followed his sister, as 'abandonment' even though he was 27 at the time. During difficult periods, however, Martin frequented his family more often, as for example after his second divorce when he did not obtain custody of his daughter and when he moved in for a short period with his parents. With his partner from his third marriage, he had recently moved to be very near to his parents-in-law, a situation which he described as a 'suffocating'. At the time of interview, the couple lived about 50 kilometres from his parents-in-law, which Martin described as the 'right distance'. He sometimes visited his own family and had set up a system whereby during holidays they could meet up in the same place. Martin still regretted that he did not function with his own family in a local family entourage mode, but he hoped to act differently with his own children. The dispersed family mode became even more undesirable when the children set up their own homes in another region. 
Rose represented another example of a baby boomer who regretted the existence of a dispersed family entourage. She had always strived hard to maintain family bonds by choosing to live near her father, then her brothers and sisters. However, her own children had decided to move away from the region, a situation that did not accord with her ideal of family functioning:

I have two children who left for the regions because the Paris area didn't suit them at all: too much traffic... They told me, 'Mum, we're leaving'. Well, so, it was harder for me to swallow than for them, I think. So now it's Christmas, birthdays, major holidays, that's cutting it tight... It's their choice and we can't go against their wish.

Rose's narrative clearly conveys an interiorised norm of reciprocal independence between parents and children. Although she respects their independence, however, she expressed her regret to see them only sporadically throughout the year.

Finally, some dispersed family entourages of the baby boomers were atypical as in the case of Agnès. For many years, Agnès lived abroad, and her physical remoteness inevitably resulted in infrequent meetings with her family, despite the fact that she had always been very close to her parents, brother, and sister and had maintained regular contact with them during her adult life. For example, Christmas holidays, were usually celebrated either at her home or her sister's or parents' home, and they were an occasion for a large convivial family get-together. However, her parents' illnesses were a major factor in Agnès' decision to return to France. She became heavily involved in caring for her parents, to the point where her own lifestyle and projects had to be modified. Agnès described at length the burden that her parents had become, and she presented herself as practically having been 'crucified my parents' situation is what prevented me from doing sort of what I wanted'. At the time of interview Agnès was somewhat isolated: her family network had shrunk following the successive deaths of her brother and father, as well as the departure of her daughter from the home. The entourage that remained (her mother, sister and sister's children, daughter, spouse) had become even more central. Moreover, these changes had recently led her to rethink her position and role within the family. Not very attached to the Parisian life-style, she was considering leaving the capital to move to a region to be closer to her family (her daughter, sister, and ill mother), the only family members who were still alive and who remained important to her. In addition, while she had contact with her parents-in-law, Agnès maintained a certain distance with them in order to avoid any family conflict (her parents-in-law did not share the same set of values). In the case of Agnès, the 'dispersed family entourage' did not work in everybody's interest, and it can be an obstacle to autonomy (Bonvalet 2003). Over the life-course, family ties can be transformed and the geographical distance between members can also change, especially when parents become frail. Under such conditions, family relationships can become strained and impinge on the baby boomers' desire for independence and autonomy from the more arduous tasks of social care within the family.

\section{Autonomous baby boomers ${ }^{8}$}

In the case of autonomous baby boomers, the family is not at the centre of an individual's relationships. Such a situation does not necessarily mean emotional 
distance and the absence of inter-generational transfers. However, the family does not work as a system, in the way which can be seen in both the local and dispersed entourage families. As such, the baby boomers may have close ties with their parents and children, but the group does not function 'as a family'. Each individual or branch of the family acts independently of each other, although the family as a whole can be mobilised where there is a special need or problem. Isolation from family members can in part be due to the position within the life-course. For example, some young adult children have stronger relationships with their friends but increase the intensity of their family ties when they have their own children. During these stages, kinship ties do therefore exist, but they do not manifest themselves as strongly as in local or dispersed family entourages. In the case of the baby boomers, some showed evidence of more distant relationships with their families over a long period of time. This was the case with Claire, who was born in 1946. She was raised in a very rigid social milieu, and as a teenager she rebelled against the authoritarianism of her parents. At the time of interview, her relationship with her parents, especially with her mother, still showed some signs of that rebellion and generational conflict. Claire remained distant from her parents, not only geographically - her parents lived 200 kilometres from Paris - but also emotionally. Claire visited her parents once every two months, but this contact was mainly driven by a feeling of obligation and duty. Claire was divorced with two sons of different fathers, and the independence that she had manifested since an early age had also been reproduced in relations with her two adult sons. Her eldest son, who lived in South-East Asia, visited her once a year, while her youngest son, who lived 'five minutes away', 'comes once or twice a month' to her home or that of her ex-husband, with whom she maintained regular contact. After their divorce, which occurred when the children were still young, he found a flat in the same building in order to have regular contact with his children. Claire maintained contact with her sons, but the intensity and regularity of the contact was less than observed in entourage families. Autonomous baby boomers are not isolated from their family, but relationships are more likely to be 'elective' and less intimate.

Several baby boomers in the study were childless, but their descriptions of family did not appear to reveal a greater degree of individualisation and distance from kinship ties. Intimate relations with siblings or nieces and nephews were apparent, as can be seen in the case of Paul in Paris, whose family relations revolved around his brother and sister and can be characterised as resembling a local family entourage. The London childless baby boomers also evoked close lateral and extended kinship ties that had many features in common with a local family entourage. John, 58 years old, who had been with his partner for 24 years and had no children, maintained contact with his geographically distant parents and siblings. Moreover, several times throughout the interview he stated that ideally he would like to live close to these family members. In some cases, the unavailability of family ties was the reason for an absence of kinship relations rather than the behaviour of the baby boomers. Henry, 56 years old and in a partnership that has lasted 32 years, made a joint decision with his partner not to have any children. Henry's family networks were particularly small because he had no siblings. However, the dearth of close family ties was compensated by a social network of friends made principally via a volunteer association. 


\section{Isolated baby boomers}

Most baby boomers belonged to a local or dispersed family entourage, and where family members were few, other forms of social networks existed. In a small number of cases, some individuals remained isolated from family despite having available kin. In the survey Proches et Parents, 'isolated' individuals, i.e. who named no family member in their social network, represented only $7 \%$, a finding that confirmed earlier French research (Blum and Le Bras 1985; Blum 1986). Age appears to be a determining factor: $11 \%$ of those over 60 were isolated as regards family, twice the proportion of those under the age of 60 (Bonvalet and Maison 1999). Not having children was the most discriminating variable (13.1\%), followed by a low level of education (11.4\%). In the Proches et Parents survey, lower social class groups were also found to be more exposed to exclusion from family life, particularly among agricultural workers, manual workers, and economically inactive individuals. The results of the survey showed that, on the one hand, where there were strong normative roles attributed to family relations (Héran 1987), being childless seemed to reinforce isolation. ${ }^{9}$ On the other hand, a kinship deficit can be attenuated through friends, especially those living in the same neighbourhood. The Proches et Parents survey identified three types of isolated individuals: those who are alone, without any network of family or friends; those who 'make up for' their lack of family through friends; and those who are in conflict with their family.

When asked to describe his social network, Hervé replied that it was a relatively simple matter. Hervé, divorced, lived alone, and his network comprised his daughters 'because they are my children and I am close to them' and his sister, whom he did not see very often even though she lived nearby. Hervé's brother was not part of his network and he had lost contact with him. Throughout the interview, Hervé mentioned several times that he had not been able to be actively engaged in bringing up his daughter, since custody was given to his ex-partner on divorce. Hervé's turbulent family history and numerous life 'accidents' had led to an increasing exclusion from family life. He described a 'fantastic childhood' passed in Algeria that was in complete contrast to his current life. His arrival in France at the age of 16 was a cultural shock, and he described it as a 'complex time that marked me'. There followed a period of instability, involving several stays in temporary accommodation as well as the geographical dispersion of the family. The early death of his mother led to a further weakening of kinship ties with his siblings. Herve's own personal life was equally unstable. He separated from his first partner shortly after the birth of their child. A second marriage produced a second daughter and a second divorce. He maintained no contact with these ex-partners and felt that he had suffered from not being involved in raising his two daughters. Recently, since he became a grandfather, Hervé had become more intimate with his eldest daughter, and this daughter was the only member of his family whom he regularly visited. Hervé had also recently experienced a third conjugal separation after eight years of 'semi-cohabitating'. Hervé was effectively isolated not only from family life but from other forms of social network, a situation that appeared among the baby boomers to be more common for men than for women. As other studies have noted, mid-life separations that result in solo living are more frequently experienced negatively by men than by women (Clément and Bonvalet 2006). Such a situation may be directly related to divorce and separation, but it is exacerbated by the tendency for men to have less dense and 
intimate social relations than women, and moreover social relations that tend to be orientated towards children (Clément and Bonvalet 2006). The fact that 'after a divorce or separation, it is more common for men to start a new couple than for women' (Cassan et al. 2001) may also indicate the greater difficulty that men have in living alone and maintaining or developing social networks than women.

In contrast to Hervé, Hélène's lack of family ties was not characterised by relational isolation, since she formed part of a 'living together-apart' couple. After the death of her father a few months earlier, her family network became dispersed. She no longer had contact with her brother, and, apart from an unwell aunt, no other family members remained. But in contrast to Hervé, Hélène had a special network of friends, in particular two childhood friends. This network of friends spent time together at different places in France, and Hélène was often invited by her friends to spend time in their second homes. Similarly, Peter was isolated from family ties but he had been able to form solid friendships, especially through his pursuit of musical activities. Born in England in 1953, Peter experienced a chaotic childhood. An adopted child, he spent the first years of his life on the Isle of Wight, and then went to North America with his parents. During his youth, he drifted into the popular music scene, playing in many local bands but never having had a stable job. At the time of interview, he divided his time between his musical activities and helping others to make use of the Internet, both of which did not provide much income.

Finally, some baby boomers' family history was especially marked by conflict which in turn had led to a reduction in family contact. The reasons for this conflict were multiple. Some conflicts were long-standing, others more recent, as for example a dispute arising from an inheritance 'received before it was time'. Sarah no longer had contact with her parents who abused her throughout her childhood and adolescence. Ida was never close to her mother in childhood, and she hardly knew her father before going to live with him as a teenager. Asked about her network, she described herself as an 'orphan', since her father died in 1993. These examples show how conflicts in family life can result in enduring reduced kinship ties that persist in mid-life and that friends can, to a certain degree, take the place of family as important providers of emotional support and practical help.

\section{Conclusion}

As they move through the life-course, the post-war generation of baby boomers continue to maintain close ties with both their ageing parents and their adult children. An analysis of their family ties reveals clearly defined family groups, such as the family entourage - both local and dispersed. Depending on the location of parents, children, and/or siblings, two types of family entourage can be observed. Firstly, the local family entourage which involves a neighbourhood-centred life-style with close family ties. This residential proximity, which facilitates exchanges while respecting the independence of family members, is particularly practical when the children of the baby boomers leave the parental home and when their parents become frail or experience illness and disability. In most cases, the baby boomers appear to have opted to function within a local family entourage, using a number of strategies to manage the location and use of homes together with family assets. One reason for this choice of being implicated in family life is that their personal fulfilment includes being parents and grandparents and the baby boomers do not necessarily experience 
the family as an impediment to their individuality. However, when inter-generational solidarity requires a reorganisation of day-to-day life, as for example in accommodating an adult child with his or her partner or taking care of a parent who is losing his or her autonomy - in other words, to create new forms of solidarity in which 'we' takes precedence over 'I' - family constraints may become overbearing, forcing baby boomers, especially women, to limit their personal activities.

Geographical distance does not necessarily weaken family relationships, as the dispersed family entourage demonstrates. Family gatherings are admittedly less frequent, but relationships are not any less intense, as witnessed by the relatively high level of telephone calls, practical assistance, and emotional ties. Holidays and weekends are all the more special as times to be shared. Family entourages are reproduced through the generations, and they shape a 'family group' capable of combining the household and lineage. For some of these families, the transmission of family wealth - keeping the family home in the family - enables them to reactivate kinship bonds, with the home symbolising the family spirit that they wish to pass down to their grandchildren. In other families, mechanisms that preserve emotional ties exist, but family gatherings are less frequent and help is provided in response to specific need. In contrast to family entourages, the family does not function as a complete system; rather it resembles a social network in which relationships are based on 'elective ties uniting people, two by two' (Weber 2002, p.89).

Family entourages and autonomous families do not cover all family configurations. There are cases, albeit rarer, in which the family over time and because of life events has withdrawn from the scene, giving way to friends or even creating social isolation. In these situations, other social ties sometimes replace the family, with voluntary and charitable associations playing an important role. In other cases, baby boomers may find themselves with a severely reduced kinship network either because of having few members or because of family conflicts. Our study, however, revealed that the majority of baby boomers in London and Paris belongs to family entourages. This large proportion stems from the position of the post-war generation, at the time of interview, as a pivot or sandwich generation, placed between ageing parents and children who are beginning their adult lives. The family entourage also constitutes a way of dealing with financial difficulties affecting the various generations, with the recent economic crisis resulting in greater family solidarity.

The fact remains that the rise in individualism, which characterises modern societies, does not seem to have jeopardised the intensity of inter-generational bonds or the existence of family groups. It would even seem, to paraphrase the title of a paper by Jean-Hugues Déchaux, that the family cannot be understood through individualism (Déchaux 2010). The logical conclusion to the promotion of the individual, who is encouraged to 'become him/herself', would be the individual's refusal to make sacrifices for the family. This thesis does not hold true given that family norms of mutual support are still present in Europe today. Jean-Hugues Déchaux effectively shows that these norms have not radically changed with the onset of modernity; rather, 'there exists a process of social construction that regulates independence, a regulation of intimacy and interpersonal relationships based on largely unpublished schemes of normativity' (Déchaux 2010, p. 96). This regulation is disseminated by the media, in particular women's magazines, via specialists (e.g. doctors, psychologists), social services for children and the family, and so forth. 
These institutions define what is a 'good couple', a 'successful education', the 'right age to have children', the 'right way to experience one's sexuality', the 'right way to get divorced' (Déchaux 2010, p. 101), and, currently, the new art of being grandparents or living in a recomposed family. In reality, 'each person has to be unique and independent but is subject to diffuse and powerful normative pressure' (Déchaux 2010, p. 104). Under these conditions, the norm of residential independence, which remains dominant in France and Britain, has led to the neardisappearance of extended family households. The way in which baby boomers have built their space or shaped their territory - most often 'as a family' but sometimes 'without family' - reveals the diversity of family modes, whether or not they continue from generation to generation.

\section{Notes}

1. See the contributions of these authors in the collective work by Susan McRae (1999).

2. See the research of Claudine Attias-Donfut (1995) and of Martine Segalen (2010); Jeux de familles (ed. Martine Segalen 1991), as well as the INSEE publications, INSEE première, no. 600 (Crenner 1998) and 631 (Crenner 1999).

3. See Jean-Hugues Dechaux's (2001) review of the work.

4. 'L'étude des relations familiales et intergénérationnelles' (ERFI). The French version of the Generations and Gender Survey (GGS), was part of the international Generations and Genders Programme (GGP) for the collection and analysis of socio-demographic population data from a large number of European countries over several years. The United Kingdom was not part of the programme.

5. According to Florence Weber, 'the household is based on a specific kinship bond: location in the proper sense of the term, coproduction and residence'. (Weber et al. 2003, p. 391).

6. While the principle of equality exists as regards the management of family relationships on both sides, a tendency towards matrilatéralité, i.e. a preference for the wife's line, can however be observed (Bonvalet and D. Maison 1999, Le Pape 2006, Jonas and Le Pape 2008).

7. In the survey Proches et Parents, it was observed that the local entourage was, all things being equal, more common in these professional categories (Bonvalet 2003).

8. In previous studies $(1999,2003)$, we called this type of family 'famille atténuée', a translation of Peter Willmott's 'kinship network'. Since 'attenuée' has a somewhat negative connotation, however, we have decided to use the term 'moderate family' (famille-modérée), which better reflects its functioning, not as a solitary group, but through two-on-two relationships.

9. See Jean-Claude Kaufmann's research on isolation (1994a, 1994b).

\section{References}

Alwin, D. F., McCammon, R.J., and Hofer, S.M., 2006. Studying boomer cohorts within a demographic and developmental context: conceptual and methodological issues. In: S. Krauss, S. Whitbourne and S.L. Willis, eds. The baby boomers grow up: contemporary perspectives on midlife. Mahwah, NJ: Lawrence Erlbaum Associates Inc., 45-71.

Attias-Donfut, C., ed., 1995. La solidarité entre les générations [Solidarity between generations]. Paris: Nathan.

Bengston, V. and Roberts, R., 1991. Intergenerational solidarity in aging families: an example of formal theory construction. Journal of Marriage and the Family, 53, 856-70.

Bertaux, D., 1987. Du monopole au pluralisme méthodologique dans la sociologie de la mobilité sociale [From monopoly to methodological pluralism in the sociology of social mobility]. Histoires de vie, histoires de familles, trajectoires sociales, Annales de Vaucression, 26,315 . 
Blum, A., 1986. Fécondité, solidarité intergénérationnelle, isolement [Fertility, intergenerational solidarity and isolation]. In: Les familles d'aujourd'hui. Geneva: Actes du Colloque d'AIDELF, no2.

Blum, A. and Le Bras, H., 1985. Solidarité familiales solidarité sociale [Family solidarity and social solidarity] In: D. Kessler and A. Masson, eds. Cycle de vie et Générations, Paris: Economica, 157-178.

Bonvalet, C., 2003. La famille-entourage [The family entourage]. Population, 1, 9-44.

Bonvalet, C. and Maison, D., 1999. Famille et entourage: le jeux des proximités [Family and entourage: the proximity game]. In: C. Bonvalet, A. Gotman and Y. Grafmeter, eds. La famille et ses proches: l'aménagement des territoires. Paris: INED. Travaux et documents, $143,27-67$.

Bonvalet, C. and Ogg, J., 2009. Les baby-boomers: une génération mobile [Baby-boomers: a mobile generation]. Paris: Editions de l'Aube.

Bonvalet, C., Clément, C., and Ogg, J., 2011. Réinventer la famille : l'histoire des baby-boomers [Reinventing the family a history of the baby-boomers] Collection 'Les liens sociales'. Paris: Presse Universitaire Française.

Bonvalet, C. and Maison, D., 1999. Famille et entourage: le jeux des proximities [Family and entourage: the proximity game]. In: La famille et ses proches: l'aménagement des territories. Paris: INED. Travaux et documents, 143, 27-67.

Bourdieu, P., 2000. Les structures sociales de l'économie [Social structure and the economy]. Paris: Seuil.

Caradec, V., 2009. Vieillir un fardeau pour les proches? [Is ageing a burden for the family?]. Lien social et Politiques, 62, 111-22.

Cassan, F., Masuy, M., and Clanché, F., 2001. Refaire sa vie de couple est plus fréquent pour les hommes [Forming a new couple is more common among men]. INSEE Première, 797

Cheal, D., 1999. The one and the many: modernity and postmodernity. In: G. Allan, ed. Sociology of the family. Oxford: Blackwell, 56-85.

Clément, C. and Bonvalet, C., 2006. Les espaces de vie des familles recomposées [Life spaces and recomposed families]. Paris: Puca.

Crenner, E., 1998. La parenté: un réseau de sociabilité actif mais concentré [Kinship: aan active and concentrated network]. INSEE Première, 600.

Crenner, E., 1999. Famille je vous aide [Helping the family]. INSEE Première, 631

Dechaux, J.-H., 2001. La famille et ses proches: l'aménagement des territoires [Family and kinship: regional patterns]. Revue Française de Sociologie, 42 (1), 186-90.

Déchaux, J. H., 2007. Sociologie de la famille [The Sociology of the Family]. Paris: La Découverte.

Dechaux, J.-H., 2010. Ce que l'individualisme ne permet pas de comprendre: le cas de la famille [What individualism cannot explain: the case of the family]. Esprit, 365, 94-111.

Glaser, B.G. and Strauss, A.L., 1967. The discovery of grounded theory: strategies for qualitative research. Chicago: Aldine Publishing Company.

Gotman, A., 1999. Géographies familiales, migrations et générations [Family geographies, migration and generations]. In: C. Bonvalet, A. Gotman, and Y. Grafmeter, eds. La famille et ses proches. L'aménagement des territoires. Paris: INED. Travaux et documents, 143.

Gribaudi, M., ed. 1999. Espaces, temporalités, stratifications: exercices sur les réseaux sociaux [Spacial and temporal stratifications: the case of social networks]. Paris: EHESS.

Héran, F., 1987. La sociabilité, une pratique culturelle [Sociability, a cultural practice]. Economie et Statistique, 216, 3-22.

Jonas, N. and Le Pape, M.-C., 2008. L'équilibre entre les lignées? Les aides données à la famille et à la belle-famille [Equality between different branches of the family? Help given to the family and step-relationships]. Population, 2, 299-315.

Kaufmann, J.-C., 1994a. Vie hors couple: isolement et lien social [Life outside the couple: isolation and social links]. Revue Française de Sociologie, XXV (4), 596-617.

Kaufmann, J.-C., 1994b. Les ménages d'une seule personne en Europe population, Septième rapport sur la situation démographique de la France [One-person households in Europe: Seventh report of the demographic situation of France]. Population, 4-5, 935-58. 
Le Pape, M.C., 2006. Hommes et femmes en milieux populaires: les ambivalences d'une double appartenance [Working class men and women: the ambivalence of belonging to two groups]. Sociétés contemporaines, 62, 5-26.

Le Play, F., 1989. La méthode sociale [The social method] (1st edition 1879). Paris: Méridiens Klincksieck.

McGlone, F., Park, A., and Roberts, C., 1999. Kinship and friendships: attitudes and behaviour in Britain, 1986-1995. In: S. McRae, ed. Changing Britain. Families and households in the 1990s. Oxford: Oxford University Press, 141-55.

McRae, S., 1999. Changing Britain. Families and households in the 1990s. Oxford: Oxford University Press.

Masson, A., 2009. Des liens et des transferts entre générations [Links and transfers between the generations]. Paris: EHESS.

Parsons, T., 1955. Éléments pour une sociologie de l'action [Elements for a sociology of action] (1st edition 1937). Paris: Plon.

Ramos, E., 2006. L'invention des origines [The invention of origins]. Paris: Armand Colin.

Reinert, M., 1993. Les 'mondes lexicaux' et leur 'logique' à travers l'analyse statistique d'un corupus de récit de cauchemars' ['Lexical worlds' and their 'logic' through a statistical analysis of narratives of nightmares] Langage et Société, 66, Paris: Maison de Sciences de l'Homme.

Reinert, M., 1995. Quelques aspects du choix des unités d'analyse et de leur contrôle dans la méthode Alceste [Some aspects of the choice of units of analysis and their control in the Alceste methodology] JADT, 1, 27-35.

Roussel, L., 1996. La solidarité intergénérationnelle- essai de perspectives [Intergenerational solidarity - essay and perspectives]. In: AIDELF, ed. Ménages, familles, parentèles et solidarités dans les populations méditerranéennes. Paris: AIDELF, 589-601.

Scanzoni, J., 1979. Social processes and power in families. In: W. Burr, R. Hill, F. L. Nye and I. Reiss, eds. Contemporary theories about the family Vol. 1. New York, NY: Free Press, 295317.

Segalen, M., ed. 1991. Jeux de famille [Family games]. Paris: CNRS

Segalen, M., 2010. The modern reality of kinship: sources and significance of new kinship forms in contemporary Europe. In: P. Heady, M. Kohli, eds. Family, kinship and state in contemporary Europe, volume 3: perspectives on theory and policy. Frankfurt: Campus Verlag, 249-70.

de Singly, F., 2009. Sociologie de la famille contemporaine [The sociology of the contemporary family]. Paris: Armand Colin.

Weber, F., 2002. Pour penser la parenté contemporaine. Maisonnée et parentèle, des outils de l'anthropologie [Thinking about contemporary kinship: domestic households and kinship ties]. In: D. Debordeaux and P. Strobel, eds. Les solidarités familiales en question. Entraide et transmission. Paris: LGDJ, 73-106.

Weber, F., Gojard, S., and Gramain, A., 2003. Charges de famille. Dépendance et parenté dans la France contemporaine [Family work. Dependency and kinship in contemporary France]. Paris: La Découverte.

Willmott, P., 1986. Social networks, informal care and public policy. London: Policy Studies Institute. 